\title{
BERPIKIR KREATIF SISWA DALAM MEMECAHKAN MASALAH KONTEKSTUAL MATEMATIKA DITINJAU DARI TIPE KEPRIBADIAN
}

\author{
Imil Hidayati \\ Prodi Pendidikan matematika, STKIP PGRI Sidoarjo \\ imilhidayati9@gmail.com \\ Achmad Dhany Fachrudin \\ Prodi Pendidikan matematika, STKIP PGRI Sidoarjo \\ dh4nyy@gmail.com \\ Siti Nuriyatin \\ Prodi Pendidikan matematika, STKIP PGRI Sidoarjo \\ sitinuriyatin@gmail.com
}

\begin{abstract}
ABSTRAK
Kemampuan berpikir kreatif merupakan keterampilan yang sangat diperlukan seseorang dalam memecahkan masalah namun setiap orang mempunyai cara berpikir kreatif yang berbeda karena setiap orang mempunyai tipe keperibadian yang beragam. Tujuan penelitian ini untuk mendeskripsikan analisis berpikir kreatif siswa dalam memecahkan masalah kontekstual matematika ditinjau dari tipe kepribadian sanguinis, koleris, melankolis, dan phlegmatis. Penelitian ini merupakan penelitian deskriptif dengan menggunakan pendekatan kualitatif dengan subjek penelitian berjumlah empat siswa kelas VII-3 SMP Negeri 1 Krembung yang setiap tipe kepribadian diwakili satu subjek. Data yang diperoleh pada penelitian ini yaitu data hasil tes kepribadian, data hasil tes pemecahan masalah kontekstual, dan data hasil wawancara. Data yang diperoleh dianalisis dengan mendeskripsikan berdasarkan komponen berpikir kreatif yaitu kefasihan, fleksibilitas, dan kebaruan. Hasil penelitian diperoleh tipe kepribadian phlegmatis dan melankolis memahami masalah dan informasi yang ada, mengungkapkan apa yang diketahui dan yang ditanyakan, dan dapat menghasilkan ide-ide yang beragam dan berbeda. Sedangkan tipe kepribadian sanguinis dan koleris belum mampu menghasilkan ide-ide yang beragam dan berbeda. Tipe kepribadian phlegmatis dan melankolis mampu memenuhi komponen kefasihan, fleksibilitas, dan kebaruan, tipe kepribadian sanguinis belum mampu memenuhi komponen kefasihan, fleksibilitas, dan kebaruan, sedangkan tipe kepribadian koleris hanya mampu memenuhi komponen kefasihan.
\end{abstract}

Kata Kunci : Berpikir Kreatif, Pemecahan Masalah Kontekstual, Tipe Kepribadian.

\section{ABSTRACT}


The ability to think creatively is a skill that is really needed by someone in solving problems, but everyone has a different creative way of thinking because everyone has various types of personality. The purpose of this study was to describe the analysis of students' creative thinking in solving contextual mathematics problems in terms of sanguine, choleric, melancholy, and phlegmatic personality types. This research is a descriptive study using a qualitative approach. The research subjects are four students of class VII-3 SMP Negeri 1 Krembung. Each personality type is represented by one subject. The data obtained in this study are personality test results, contextual problem solving test results, and interview data. The data obtained were analyzed by describing the components of creative thinking, namely fluency, flexibility, and novelty. The research results were obtainedphlegmatic and melancholy personality types understand the problem and the information at hand, reveal what is known and asked, and can generate diverse and different ideas. Meanwhile, sanguine and choleric personality types have not been able to generate diverse and different ideas. Phlegmatic and melancholy personality types are able to fulfill fluency, flexibility, and novelty components, sanguinis personality types have not been able to fulfill fluency, flexibility, and novelty components, whereas choleric personality types are only able to fulfill fluency components.

Keywords : Creative Thinking, Contextual Problem Solving, Personality Type.

\section{PENDAHULUAN}

Dalam pendidikan di Indonesia pemerintah telah menyempurnakan kurikulum 2013. Salah satu tujuannya adalah untuk mempersiapkan warga negara Indonesia yang kreatif serta mampu berkontribusi pada kehidupan bermasyarakat, dengan begitu kemampuan berpikir kreatif merupakan hal yang sangat diperlukan untuk seseorang dalam mendorong keterampilan dalam memecahkan masalah. Kemampuan berpikir kreatif merupakan potensi yang harus dimiliki siswa karena sangat dibutuhkan dalam menghadapi persoalan matematika, bukan hanya dibutuhkan dalam memecahkan masalah matematika, melainkan juga dibutuhkan dalam memecahkan masalah yang berkaitan dengan kehidupan sehari-hari (Machromah, Riyadi \& Usodo, 2015; Effendi \& Farlina, 2017; Mulyaningsih \& Ratu, 2018; Hasanah \& Putra, 2017).

Kemampuan siswa dalam memecahkan masalah konteks masih rendah dibandingkan kemampuan siswa dalam memecahkan masalah yang tidak berbasis konteks dunia nyata (Simalango, 
2018; Nasriadi, Sari, 2017; Mena, Lukito \& Siswono, 2016 ). Mengingat pentingnya berpikir kreatif siswa dalam memecahkan masalah kontekstual matematika maka siswa perlu dilatih untuk menggali berpikir kreatif siswa dalam memecahkan masalah kontekstual matematika. Silver (1997) menjelaskan berpikir kreatif sering digunakan The Torrance Test of Creative Thinking (TTCT). Komponen yang dinilai dalam berpikir kreatif menggunakan TTCT, yaitu kefasihan (fluency), fleksibilitas (flexibility), dan kebaruan (novelty). Menurut Fitria dan Siswono (2014) dalam penelitiannya menunjukkan hasil bahwa setiap siswa dalam berpikir kreatif berbeda-beda. Karakteristik kepribadian siswa yang disebabkan oleh perbedaan pengaruh, baik dari faktor intern maupun ekstern (Oktaviana \& Susiaty, 2017).

Kepribadian adalah organisasi dinamis dan yang menentukan tingkah laku dan pemikiran individu yang khas. Hippocrates dan Galenus dalam karangan Florence Littauer membagi tipe kepribadian berdasarkan zat cair yang ada dalam tubuh seseorang, yaitu melancholicus (melankolis), sanguiniscus (sanguinis), flagmaticus (phlegmatis), dan cholericus (koleris). Dengan begitu peneliti terdorong melakukan penelitian berpikir kreatif siswa dalam memecahkan masalah kontekstual ditinjau dari tipe kepribadian
(Sanguinis, Phlegmatis, Koleris, Melankolis) karena masalah kontekstual berpengaruh penting dalam berpikir kreatif.

Penggunaan masalah kontekstual matematika memungkinkan siswa untuk mengembangkan pola berpikir yang lebih kompleks karena melibatkan pengetahuan matematika formal dan informal (Anggo, 2011). Berdasarkan paparan diatas maka dapat dijadikan rumusan masalah bagaimana analisis berpikir kreatif siswa dalam memecahkan masalah kontekstual matematika ditinjau dari tipe kepribadian. Tujuan penelitian ini untuk mendeskripsikan analisis berpikir kreatif siswa dalam memecahkan masalah kontekstual matematika ditinjau dari tipe kepribadian.

Peneliti ini menggunakan jenis penelitian deskriptif dengan pendekatan kualitatif. Penelitian ini dilaksanakan dengan subjek penelitian siswa kelas VII SMP Negeri 1 Krembung dengan jumlah empat siswa. Penelitian ini dilaksanakan dengan cara memberikan soal yang merupakan masalah kontekstual kepada siswa. Subjek penelitian dipilih berdasarkan tipe kepribadian yang diperoleh dari hasil tes kepribadian siswa (sanguinis, koleris, melankolis, dan phlegmatis), selanjutnya dipilih satu subjek yang komunikatif dan mempunyai 
kemampuan yang ekuivalen dari masingmasing tipe kepribadian dengan rekomendasi dari guru matematika.

Instrumen yang digunakan dalam penelitian ini adalah tes kepribadian, tes berpikir kreatif siswa dalam memecahkan masalah kontekstual, pedoman wawancara. Tes kepribadian diadopsi dari buku karangan Florence Littauer yang berjudul Personality Plus. Tes pemecahan masalah berupa soal uraian masalah kontekstual. Wawancara yang digunakan adalah wawancara semi terstruktur. Proses analisis data pada penelitian ini memuat tiga alur kegiatan, yakni reduksi data, penyajian data, dan penarikan kesimpulan. Pengumpulan data dilakukan secara obyektif sesuai dengan hasil tes kepribadian, hasil tes pemecahan masalah kontekstual matematika, dan hasil wawancara, kemudian disimpulkan secara deskriptif dengan melihat data-data yang ditemukan selama proses penelitian.

\section{HASIL DAN PEMBAHASAN}

Pelaksanaan penelitian yang pertama dilaksanakan dengan memberikan tes kepribadian pada kelas VII-3 SMP Negeri 1 Krembung dengan jumlah 31 siswa. Hasil tes kepribadian diperoleh 5 siswa bertipe kepribadian sanguinis, 9 siswa bertipe kepribadian koleris, 3 siswa bertipe kepribadian melankolis, 13 siswa bertipe kepribadian phlegmatis, dan 1 siswa bertipe kepribadian ganda yaitu sanguinis dan phlegmatis. Dari hasil tes kepribadian akan diambil satu siswa dari masing-masing tipe kepribadian yang akan dijadikan subjek penelitian. Berikut hasil dari pengamatan dari empat subjek yang telah mengerjakan soal masalah kontekstual dan telah diwawancarai.

\section{Analisis dan Pembahasan Berpikir Kreatif Siswa dalam Memecahkan Masalah Kontekstual Matematika Bertipe Kepribadian Phlegmatis}

Berikut ini adalah hasil tes dan kutipan wawancara siswa bertipe kepribadian phlegmatis dalam memecahkan masalah kontekstual matematika pada indikator kefasihan:

P.1 : Apakah kamu memahami dari soal disajikan ini?

PH.1 : Iya.

P.2 : Apakah kamu dapat menduga dengan cepat kemungkinan solusi dari soal yang disajikan?

PH.2 : Iya bisa.

Dari transkip wawancara yang terpaparkan di atas, terlihat bahwa $\mathrm{PH}$ mampu memahami soal yang disajikan dan dapat menduga dengan cepat kemungkinan solusi penyelesaiannya. Hal tersebut menunjukkan bahwa $\mathrm{PH}$ dapat menyelesaikan masalah kontekstual matematika yang disajikan. 


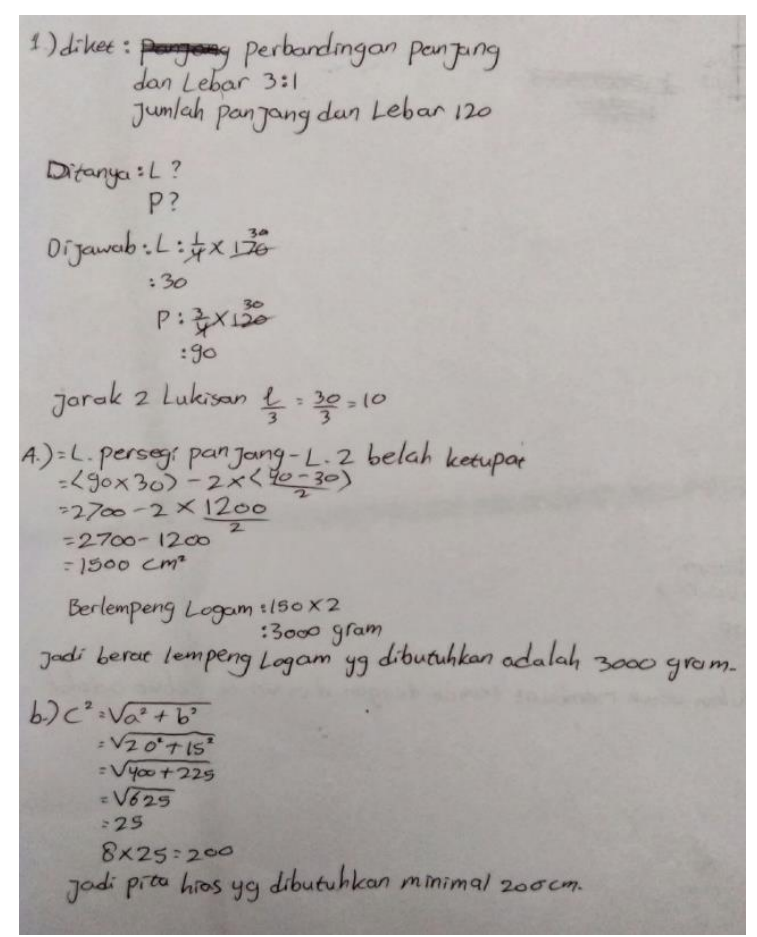

Gambar 1 Jawaban PH pada soal nomor 1

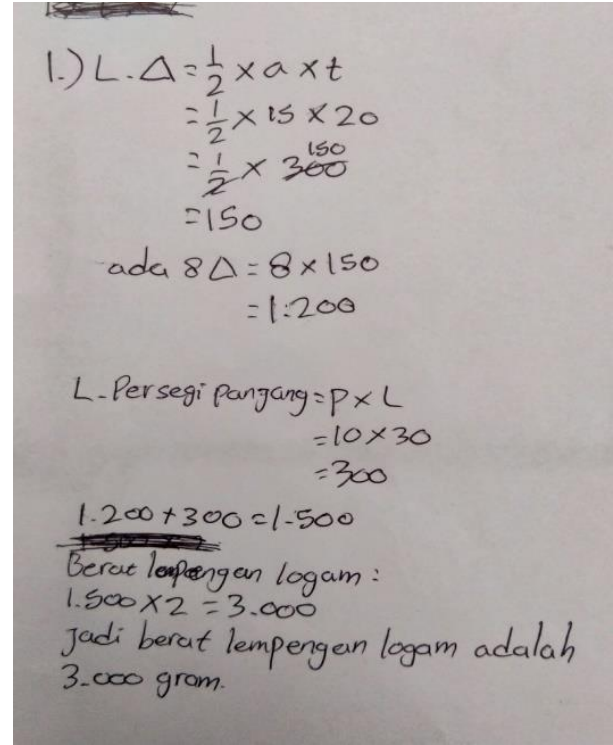

Gambar 2 Alternatif jawaban lain PH pada soal nomor 1

P.3 : Bisakah kamu menjelaskan hasil pekerjaan kamu pada nomor 1 ?

PH.3 : Iya bisa, yang diketahui perbandingan panjang dan lebar, yang ditanyakan berat lempengan logam yang tidak ditempeli lukisan dan minimal panjang pita yang dibutuhkan. Mencari panjang dan lebarnya terlebih dahulu, lalu mencari luas persegi panjang dikurangi luas belah ketupat hasilnya dikalikan 2 karena luas $1 \mathrm{~cm}^{2}$ beratnya 2 gram. Itu yang a. kak, yang $b$. pakek teori phytagoras untuk mencari sisi miringnya. Karena ada 2 lukisan saya kalikan 2.

P.4 : Apakah kamu memilik beragam ide untuk penyelesaian nomor 1 ?

PH.4 : Iyakak.

P.5 : Bisakah kamu menjelaskannya?

PH.5 : Bisa. Ini ada 8 segitiga, mencari luas segitiga lalu dikalikan 8 dan mencari luas persegi panjang ini lalu dijumlahkan.

Dalam menyelesaikan soal nomor 1 PH mampu memberikan beragam penyelesaian dengan benar. Penyelesaian yang pertama terlihat pada gambar 1 \& penyelesaian yang kedua terlihat pada gambar 2. Pada kutipan wawancara untuk penjelasan dari penyelesaiannya terlihat pada kutipan PH.3 


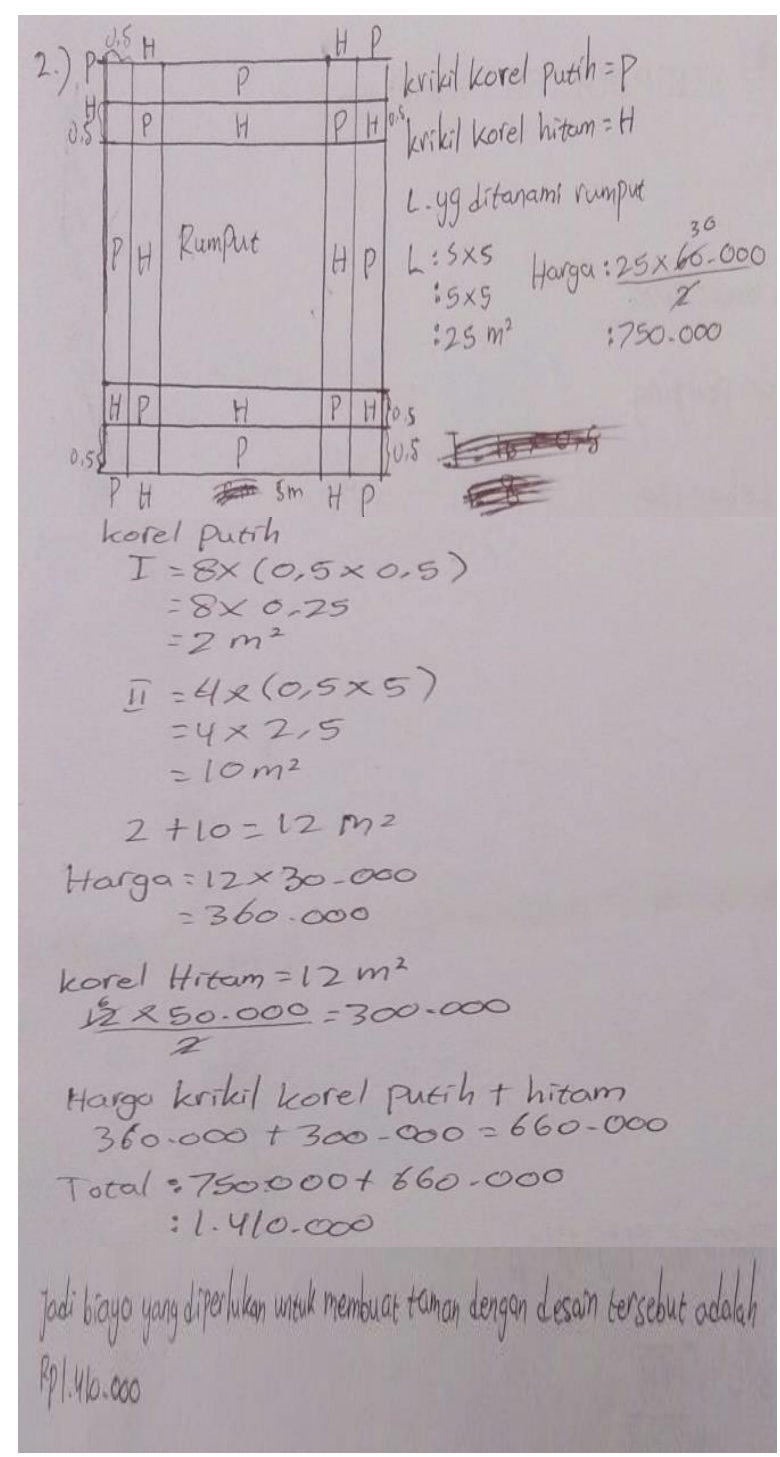

Gambar 3 Jawaban PH pada soal nomor 2

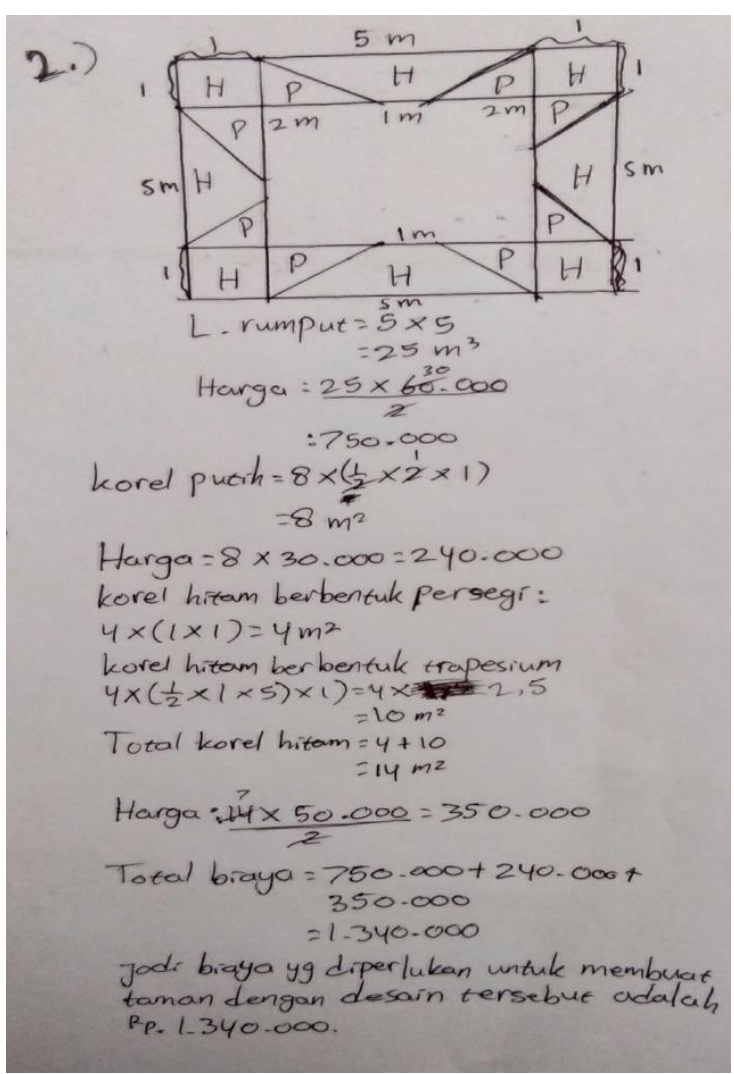

Gambar 4 Alternatif jawaban lain PH pada soal nomor 2

P.6 : Untuk nomor 2 bisakah kamu menjelaskan hasil pekerjaan kamu?

PH.6 : Iya, ini sisinya berjarak $1 \mathrm{~m}$ saya begi 2 semua lalu mencari biayanya korel putih dan korel hitam dan rumput lalu dijumlah sетиа.

P.7 : Pada nomor 2 apakah kamu dapat memikirkan ide yang beragam?

PH.7 : Iya dapat.

P.8 : Bisakah kamu menjelaskannya?

PH.8 : Bisa. Ini pojok-pojoknya berbentuk persegi saya beri korel hitam dan sisanya ditengah saya bentuk trapesium dengan korel hitam dan pinggir-pinggir 
berbentuk segitiga saya beri korel putih. Lalu menentukan luasnya masing-masing kemudian dikalikan dengan biaya yang sudah ditentukan.

Pada soal nomor 2 terlihat dari kutipan wawancara menunjukkan bahwa PH mampu memberikan penyelesaian yang beragam. Penyelesaian yang pertama seperti pada gambar 3 dan penyelesaian yang kedua seperti pada gambar 4 dan transkip wawancara PH.8 dengan penjelasannya, dari hasil penyelesaiannya PH mampu memecahkan masalah kontekstual pada nomor 1 dan 2 dengan benar dan juga mampu menghasilkan penyelesaian yang beragam sehingga $\mathrm{PH}$ mampu memenuhi komponen kefasihan.

Berikut ini adalah hasil tes dan kutipan wawancara siswa bertipe kepribadian phlegmatis dalam memecahkan masalah kontekstual matematika pada indikator fleksibilitas:

P.9 : Apakah kamu memiliki alternatif penyelesaian yang lain untuk nomor 1?

PH.9 : Iya kak.

P.10 : Bisakah kamu menjelaskannya?

PH.10 : Bisa. Ini ada 8 segitiga, mencari luas segitiga lalu dikalikan 8 dan mencari luas persegi panjang ini lalu dijumlahkan.
P.11 : Pada nomor 2 apakah kamu dapat memikirkan ide yang berbeda?

PH.11 : Iya dapat.

P.12 : Bisakah kamu menjelaskannya?

PH.12 : Bisa. Ini pojok-pojoknya berbentuk persegi saya beri korel hitam dan sisanya ditengah saya bentuk trapesium dengan korel hitam dan pinggirpinggir trapesium berbentuk segitiga saya beri korel putih. Lalu menentukan luasnya masing-masing kemudian dikalikan dengan biaya yang sudah ditentukan.

Berdasarkan hasil jawaban pada gambar $1 \& 2$ dan transkip wawancara di atas $\mathrm{PH}$ dalam memecahkan masalah kontekstual matematika pada soal nomor 1 mampu menghasilkan beragam ide penyelesaian yang berbeda. Dalam penyelesaiannya pada soal nomor $1 \mathrm{PH}$ menghasilkan ide penyelesaian yang pertama terlihat pada gambar 1 dengan menentukan berat lempengan logam yang tidak ditempeli lukisan dengan menentukan luas persegi panjang dikurangi luas dua belah ketupat. Hasil pemikiran ide penyelesaiannya yang kedua terlihat pada gambar 2 dan kutipan wawancara PH.10 dengan menentukan luas 8 segitiga pada bingkai yang tidak ditempeli lukisan dan mencari luas persegi panjang yang berada 
diantara 2 belah ketupat kemudian dijumlahkan.

Pada soal nomor 2 PH menghasilkan ide penyelesaiannya yang pertama yang terlihat pada gambar 3 dengan desain taman yang pada sisinya dibagi 2 bagian semua untuk diberi batu krikil jenis korel hitam dan putih. Ide penyelesaian yang kedua yang terlihat pada gambar 4 dan kutipan wawancara PH.12 yang mana bagian pojok-pojoknya dibentuk persegi untuk batu krikil jenis korel hitam. Sisanya ditengah-tengahnya berbentuk trapesium untuk batu krikil jenis korel hitam dan disamping bentuk trapesium berbentuk segitiga untuk batu krikil jenis korel putih. Berdasarkan hasil penyelesaiannya $\mathrm{PH}$ mampu memenuhi komponen fleksibilitas.

Berikut ini adalah hasil tes dan kutipan wawancara siswa bertipe kepribadian phlegmatis dalam memecahkan masalah kontekstual matematika pada indikator kebaruan:

Hasil jawaban pada gambar 1, 2, 3 \& 4 menunjukkan bahwa $\mathrm{PH}$ dalam memecahkan masalah kontekstual mampu memberikan penyelesaian yang berbeda dari yang lainnya dengan benar. Berdasarkan hal tersebut maka PH mampu memenuhi komponen kebaruan.

Dalam memecahkan masalah kontekstual, siswa bertipe kepribadian phlegmatis tenang dan tidak tergesa-gesa dalam mengerjakan, tenang namun cerdas, mengerjakan dengan cara yang mudah. Sehingga siswa bertipe kepribadian phlegmatis dalam memecahkan masalah kontekstual mampu memenuhi komponen kefasiahn, fleksibilitas, dan kebaruan. Hal ini sesuai dengan tipe kepribadian phlegmatis dari teori Hippocrates-Galenus (Littauer, 2011) yang menyatakan bahwa tipe peribadian phlegmatis cakap dan mantap, damai dan mudah sepakat, punya kemampuan administrative, menjadi penengah masalah, menghindari konflik, baik di bawah tekanan, menemukan cara yang mudah.

Hasil analisis siswa bertipe kepribadian phlegmatis dalam memecahkan masalah kontekstual memenuhi komponen berpikir kreatif. Hal ini senada dengan penelitian yang dilakukan oleh Fitria \& Siswono (2014) dan Aziz (2018) siswa bertipe kepribadian phlegmatis memenuhi komponen berpikir kreatif, yaitu komponen kefasihan, fleksibilitas, dan kebaruan dalam memecahkan masalah matematika.

\section{Analisis dan Pembahasan Berpikir Kreatif Siswa dalam Memecahkan Masalah Kontekstual Matematika Bertipe Kepribadian Sanguinis}

Dalam memecahkan masalah kontekstual, siswa bertipe kepribadian sanguinis belum mampu memberikan beragam penyelesaian dan beragam ide 
penyelesaian yang berbeda dalam menentukan ukuran pada lukisan \& bingkai. Dalam mendesain taman siswa mampu memberikan penyelesaian yang beragam dan beragam ide penyelesaian yang berbeda akan tetapi penyelesaiannya masih belum benar karena salah dalam menentukan ukuran untuk desain yang dibuatnya, kemungkinan kurang dalam memahami apa yang diketahui pada soal. Sehingga siswa bertipe kepribadian sanguinis belum mampu memenuhi komponen kefasihan, fleksibilitas, dan kebaruan.

Dalam pengerjaan masalah kontekstual yang disajikan, siswa bertipe kepribadian sanguinis antusias, tampak hebat dalam menyelesiannya dan memulai dengan cara yang cemerlang, namun siswa bertipe kepribadian sangunis dalam penyelesaiannya kurang dalam memehami soal akibatnya hasil penyelesaiannya kurang tepat. Hal ini sesuai dengan tipe kepribadian sanguinis dari teori Hippocrates-Galenus (Littauer, 2011) yang menyatakan bahwa tipe peribadian sanguinis sukarelawan untuk tugas, memikirkan kegiatan baru, tampak hebat di permukaan, kreatif dan inovasi, punya energi dan antusiasme, mulai dengan cara yang cemerlang, mengilhami orang lain untuk ikut, dan mempesona orang lain untuk bekerja.
Hasil analisis siswa bertipe kepribadian sanguinis dalam memecahkan masalah kontekstual tidak memenuhi indikator berpikir kreatif. Hal ini tidak senada dengan penelitian yang dilakukan oleh Fitria \& Siswono (2014) yang menyatakan siswa bertipe kepribadian sanguinis memenuhi komponen berpikir kreatif. Hasil penelitian yang diperoleh oleh peneliti berbeda juga dengan hasil yang diperoleh oleh penelitian yang dilakukan oleh Aziz (2018) yang menyatakan siswa bertipe kepribadian sanguinis dalam memecahkan masalah matematika memenuhi komponen kefasihan, dan fleksibilitas, namun tidak memenuhi komponen kebaruan.

\section{Analisis dan Pembahasan Berpikir Kreatif Siswa dalam Memecahkan Masalah Kontekstual Matematika Bertipe Kepribadian Koleris}

Dalam memecahkan masalah kontekstual, siswa bertipe kepribadian koleris belum mampu memberikan beragam penyelesaian dan beragam ide penyelesaian yang berbeda dalam menentukan ukuran pada bingkai \& lukisan. Pada desain taman siswa mampu memberikan beragam penyelesaian namun ide penyelesaiannya tidak berbeda. Dalam penyelesaian masalah kontekstual matematika siswa bertipe kepribadian koleris melihat seluruh informasi pada 
soal, bergerak dengan cepat untuk segera menyelesaikan, mencari pemecahan masalah yang mudah, dan terorganisasi dengan baik, namun hasil penyelesaian siswa bertipe kepribadian koleris belum mampu memberikan sesuatu yang berbeda dan baru akan tetapi dapat memberikan penyelesaian dengan benar.

Hal tersebut sesuai dengan tipe kepribadian koleris dari teori HippocratesGalenus (Littauer, 2011) yang menyatakan bahwa tipe kepribadian koleris berorientasi target, melihat seluruh gambaran, terorganisasi dengan baik, mencari pemecahan praktis, bergerak dengan cepat untuk bertindak, mendelegasi pekerjaan, menekankan pada hasil, merangsang kegiatan dan berkembang karena saingan. Hasil analisis siswa bertipe kepribadian koleris mampu memenuhi komponen kefasihan, namun belum mampu memenuhi komponen fleksibilitas dan komponen kebaruan, sehingga siswa bertipe kepribadian koleris tidak memenuhi indikator berpikir kreatif. Hal tersebut senada dengan penelitian yang dilakukan oleh Fitria \& Siswono (2014) dan Aziz (2018) bahwa tipe kepribadian koleris tidak memenuhi komponen berpikir kreatif.

\section{Analisis dan Pembahasan Berpikir Kreatif Siswa dalam Memecahkan}

Masalah Kontekstual Matematika Bertipe Kepribadian Melankolis

Dalam memecahkan masalah kontekstual, siswa bertipe kepribadian melankolis mampu memahami masalah kontekstual matematika yang disajikan, siswa mampu memberikan penyelesaian yang beragam dan beragam ide penyelesaian yang berbeda dalam menentukan ukuran pada bingkai \& lukisan dan juga dalam mendesain taman. Siswa bertipe kepribadian melankolis juga mampu memberikan ide penyelesaian yang berbeda dari yang lain dengan benar. Pada penyelesaian masalah kontekstual siswa bertipe kepribadian melankolis terorganisasi dengan baik, cermat dalam melihat masalah maupun penyelesaiannya, sadar akan rincian dan dapat memberikan pemecahan yang kreatif. Sehingga siswa bertipe kepribadian melankolis dalam memecahkan masalah kontekstual memenuhi komponen kefasihan, fleksibilitas, dan kebaruan.

Hasil analisis menunjukkan siswa bertipe kepribadian melankolis dalam memecahkan masalah kontekstual memenuhi komponen berpikir kreatif. Hal tersebut sesuai dengan tipe kepribadian melankolis dari teori Hippocrates-Galenus (Littauer, 2011) yang menyatakan bahwa tipe peribadian melankolis berorientasi jadwal, perfeksionis, standart tinggi, sadar 
perincihan, gigih dan cermat, tertip dan terorganisasi, teratur dan rapi, ekonomis, melihat masalah, mendapat pemecahan kreatif, perlu menyelesaikan apa yang dimulai, dan suka diagram, grafik, bagan, dan daftar.

Hal ini senada dengan penelitian yang dilakukan oleh Fitria \& Siswono (2014) dengan hasil penelitiannya siswa bertipe kepribadian melankolis memenuhi komponen berpikir kreatif. Hasil penelitian yang diperoleh oleh peneliti berbeda dengan hasil yang diperoleh oleh penelitian yang dilakukan oleh Aziz (2018) yang menyatakan siswa bertipe kepribadian melankolis dalam memecahkan masalah matematika hanya memenuhi komponen kefasihan.

\section{SIMPULAN}

Berdasarkan hasil penelitian dan pembahasan yang telah diuraikan, maka dapat disimpulkan bahwa analisis berpikir kreatif siswa dalam memecahkan masalah kontekstual matematika ditinjau dari tipe kepribadian yaitu siswa bertipe kepribadian sangiunis dan koleris belum mampu memahami masalah kontekstual yang disajikan. Siswa bertipe kepribadian sanguinis dan koleris belum mampu memenuhi komponen kefasihan, fleksibilitas, dan kebaruan. Siswa bertipe kepribadian melankolis dan phlegmatis mampu memahami masalah kontekstual yang tersajikan. Siswa bertipe kepribadian phlegmatis mampu memenuhi komponen kefasiahan, fleksibilitas, dan kebaruan.

\section{DAFTAR PUSTAKA}

Anggo, M. (2011). Pelibatan Metakognisi dalam Pemecahan Masalah Matematika. Jurnal Edumatika.

Azis, N.A., (2018). Profil Keterampilan Berpikir Kreatif Siswa Dalam Memecahkan Masalah Matematika Ditinjau Dari Kepribadian. Jurnal Matematika dan Pembelajaran.

Fitria, C. \& Tatag Y.E.S., (2014). Profil Keterampilan Berpikir Kreatif Siswa dalam Memecahkan Masalah Matematika Ditinjau dari Tipe Kepribadian (Sanguinis, Koleris, Melankolis, dan Phlegmatis). Surabaya : MATHEdunesa.

Littauer, F. (2011). Personality Plus (Kepribadian Plus). Tangerang: Karisma Publishing Group.

Oktaviana, D \& Susiaty, U.D. (2017). Perbedaan Prestasi Belajar Matematika Ditinjau Dari Tipe Kepribadian Siswa Dalam Pembelajaran Matematika. Jurnal SAP.

Silver, E.A. (1997). Fostering Creativity through Instruction Rich In Mathematical Problem Solving and Thinking in Problem Posing. International Journal On Mathematics Education.

Simalango, M.M., dkk. (2018). Kesulitan Siswa Dalam Menyelesaikan Soal-Soal PISA pada Konten Change And Relationship Level 4,5, dan 6 di SMPN I Indralaya. Jurnal Pendidikan Matematika.

Machromah, I.U., dkk. (2015). Analisis proses dan tingkat berpikir kreatif siswa smp dalam pemecahan masalah bentuk soal cerita materi lingkaran ditinjau 
dari kecemasan matematika. Jurnal Pendidikan Matematika.

Mulyaningsih, T. \& Ratu, N. (2018). Analisis kemampuan berpikir kreatif siswa smp dalam memecahkan masalah matematika pada materi pola barisan bilangan. Jurnal Ilmiah Pendidikan Matematika.

Nasriadi, A. \& Sari, K. (2017). Kemampuan siswa memecahkan soal setara pisa konteks pekerjaan : studi pengembangan soal pisa konten change and relationship. STKIP Bina Bangsa Getsempena.

Mena, A.B., dkk. (2016). Literasi matematis siswa SMP dalam menyelesaikan masalah kontekstual ditinjau dari adversity quotient (AQ)" Semarang: Kreano, Jurnal Matematika Kreatif-Inovatif.

Hasanah, U. \& Putra, R.W.Y. (2017). analisis proses berpikir kreatif dalam memecahkan masalah matematika ditinjau dari tipe kepribadian rational dan artisan. UIN Raden Intan Lampung.

Effendi, K.N.S. \& Farlina, E. (2017). Kemampuan berpikir kreatif siswa SMP kelas VII dalam penyelesaian masalah stastistika. Jurnal Analisa. 